\title{
LESSON PLANNING IN EFL CLASSROOM: A CASE STUDY IN LESSON PLAN PREPARATION AND IMPLEMENTATION
}

\author{
Raynesa Noor Emiliasari ${ }^{* 1}$, Ida Siti Jubaedah ${ }^{* 2}$ \\ raynesanoor@gmail.com ${ }^{* 1}$, idasitijubaedah@ gmail.com *2 \\ Faculty of Teachers Training and Education Science \\ Universitas Majalengka
}

\begin{abstract}
Lesson planning is an important stage that must be done by the teacher before teaching. Through careful planning, the learning process will be more organized. However, based on preliminary studies, it is known that teachers still have difficulties in preparing learning. Even though the learning has been prepared, the learning process goes beyond the plan.This study aims to: 1) explore the teachers'preparationof teaching English; and 2) investigate the implementation of teachers' lesson plan in teaching English.As a case study, the research site was in three of secondary schools in Majalengka. Three English teachers were involved as respondents.Interview, observation, and documentation were used to collect the data. The findings showed that teachers prepared the lesson plan by: 1) reviewing the core compentence and basic competence from the syllabus; 2) searching for learning resources; 3) choosing learning media; 4) determining the material; 5) selecting learning method; 6) compiling indicators and goals. However,the activities compiled in the lesson plan were not all implemented. Some disorders occured during the learning process because of teachers behalf, such as meeting, teachers profesionalism training, and other schools' activities. If some learning activitiesdid not implemented, the teachers made transactional decision to make up the class.
\end{abstract}

Keywords : Lesson Planning, Teaching English, Preparation, Implementation.

\section{INTRODUCTION}

Lesson planning is an initial step before the learning process takes place.It helps teachers to organize their learning processto avoid dead ends.With a good planning, teachers will be more confident while teaching.

Every teachers' thought in planning a lesson is usually written down in a lesson plan. A lesson plan describes in detail of learning process which consists of material to be taught, method, time, place as well as students evaluation (Neisari and Heidari, 2014).

However, although the teachers have realized that lesson plan is an important toolin teaching and learning process, they still face difficulties in making it. Some 


\section{Raynesa Noor Emiliasari ${ }^{*}$, Ida Siti Jubaedah ${ }^{*^{2}}$ \\ LESSON PLANNINGIN EFL CLASSROOM: A CASE STUDY IN LESSON PLAN \\ PREPARATION AND IMPLEMENTATION}

research in EFL context showed that EFL teachers faced some difficulties in designing a lesson plan in terms of formulating learning outcome, and indicators, selecting materials, determining learning activities, selecting materials and learning resources, time allocation and developing assessment procedure (Permana, 2010; Farid 2014; Saputri, 2017), determining learning method and media (Marliani, 2017). Another research found that time availability, the difficulty in constructing assessment and the lack of contextual training are the causes of the difficuty of designing a lesson plan (Jasmi, 2014).

From thosefindings, it can be seen that designing a lesson plan is challenging for EFL teachers. But, although it is difficult and challenging, teachers still need to take notice of steps in preparing a lesson plan in order to make an ideal lesson plan.

In preparation step, teachers should concern several steps in compiling a lesson plan. Ali Bin-Hady and Abdulsafi (2018) mentioned that before planning any daily lesson the teacher should; 1) read material that is relevant to what will be taught, 2) think about the objectives and procedures that will be used, 3) think about the difficulties that will be faced by students so that the teacher can adjust to the material to be given, 4) pay attention to the time needed for each stage of learning that the teacher will carry out, 5) ensure the teacher gives sufficient time for interaction between teacher and student, 6) each teacher tries to add various activities in learning.

In Indonesia, since the curriculum uses the 2013 curriculum, the Minister of National Education Regulation Number 103 Year 2013 mentioned several components guiding teachers in designing a 2013 curriculum lesson plan, they are : main competence (KI), basic competence, indicator, objective, material, teaching activity, assessment and resources. In order to develop the lesson plan, teachers should notice these stages: analyzing syllabus, identifying learning material, deciding learning aims, developing learning activity, formulatting assessment, decideng time allocation, and deciding learning sources (attachment of the Minister of National Education Regulation Number 81a Year 2013, Kerangka Dasar dan Struktur Kurikulum).

In addition, teachers also need to consider students' abilities, interests and number, teachers' learning management, teaching methods, and habits, learning material, and facilities and time available (Wardani in Zendrato, 2016).

So, it can be concluded that in order to make an ideal lesson plan, there are several steps that teachers must do. A good preparation may minimize the difficulties in designing a lesson plan. After teachers plan the teaching process, they certainly will implement the plan during the process. But, based on the initial study conducted in one of junior high schools in Majalengka, the lesson plan designed by teachers was not implemented perfectly during the learning process.

Build upon the teachers' difficulties in designing a lesson plan, questions arise about teachers' readiness and preparation in designing a lesson plan. This recent 
study tries to explore the teachers' preparation of designing a lesson plan in teaching English. The things that teachers do in designing a lesson plan will be discussed.Beside that, this study also wants to investigate whether the lesson plan designed by the teachers is in accordance with its implementation in the learning process.

\section{METHODOLOGY}

This study is a qualitative research with case study design since it describes a phenomena of teachers' stategies in preparinga lesson plan as well as its implementation in learning process. As Yin (2003) cited in Karlsson (2016) said that a case study is a research strategy that help us understand phenoma in real-life situations and the strategy is commom in a wide range of fields, such as psychology, sociology, political science, social work and business.

This study involved three English teachers fromthreesecondary schools in Majalengka, West Java.The data gathered from the document analysis, observation and a set of interview. Lesson plan of three English teachers were analyzed to see whether they were relevant with the steps of designing lesson plan. Observations were conducted to observe if the teaching and learning process was organized based on the lesson plan. The interviews to three English teachers were conducted in order to reveal what steps teachers taken in preparing the lesson plan. The data were analyzed using the interactive model by Miles and Huberman (1994) cited in Farid (2014) which divides the data analysis procedures into three steps; data reduction, data display and drawing conclusion and interpretation.

\section{FINDINGS AND DISCUSSION}

As a result of lesson plan analysis, it turns out that the format of lesson plans prepared by the respondents of the research have met the minimum element which is provided by the Minister of National Education Regulation Number 22 Year 2016. The lesson plan element of three respondents consists of school identity, time allotment, main competence, basic competence, indicators, learning material, teaching activities, assessment and evaluation, learning medias and resources.Based on the statement from one of the respondents, the lesson plan format has been provided by lesson plan development team. According to her, preparing a lesson plan is not a difficult thing since teachers adjust the lesson plan from the syllabus and follow the development team instruction. Other respondent said that lesson plan could be arranged by the teacher itself or by MGMP (Musyawarah Guru Mata Pelajaran).

From the explanation above, it can be concluded that teachers have been given examples and training in preparing lesson plan. They can also makelesson plan with their colleagues at MGMP. So, if they faced difficulties in making lesson plan, they can discuss it with their colleagues. 


\section{Teachers' Preparation in Designing a Lesson Plan}

Based on the interview to three English teachers related to their preparation in designing a lesson plan, the data showed that the respondents reviews the syllabus to see the main competence (KI) and basic cometence (KD). As the first respondent (R1) said that after she wrote the course identity, she reviewed the main competence (KI) and basic competence (KD) from the syllabus, then she adjusted the KD with her students' competencies.

R1: "Usually, I begin with fulfilling the course identiy, such as the name of the course, grade, and time allotment. Then, I read the syllabus to see the main and basic competence (KI and KD).I wrote those competencies in the lesson plan and I adjusted them with y students competencies."

The next step that R1 did was determining material, learning sources and media, the assessment criteria and evaluation,.

R1: "After I reviewed KI and KD, I started to determine the material. In determining the material, I need to choose which material that is suitable for my students. The material also should be adjusted with the allocation time and facilities. I also prepared the learning sources and media. Then, I set the assessment criteria as well as the evaluation to check if the material had been understood by students or if the learning objectives is achieved or not."

The steps that the second respondent (R2) taken in preparing a lesson plan were not much different with the steps that R1taken. He began his lesson plan design with determining the indicator, learning objective, teaching method, learning resources and evaluation.

R2: "Once I set the indicator of the learning, I determined the objective of the learning. I prepare the teaching method which is suitable with the material, I searched the sources from the book or internet and then I designed the evaluation."

Meanwhile, the third respondent (R3) mentioned that:

R3: "I observe the syllabus, then I started to make a lesson plan. A lesson plan was derived from the syllabus. A lesson plan should be made to achieve the KD that was written in the syllabus. A lesson plan can applied in one or two or maybe three meetings. Teachers arranged the lesson plan adjusted with the schedule in the school."

From the R3's statement, it can be concluded that lesson plan was derived from the syllabus to achieve basic competence (KD). A lesson plan was arranged for every KD which can be implemented in one or more meeting. Teachers designed the fragment of lesson plan for every meeting that was adjusted by scheduling in the education unit. 
From the steps that R1, R2 and R3 were taken in designing a lesson plan, it can be seen that all the respondents have fulfilled most of the components from the attachment of the Minister of National Education and Culture Regulation Number 81a Year 2013, Kerangka Dasar dan Struktur Kurikulumin designing a 2013 curriculum lesson plan, which are: main competence (KI), basic competence $(\mathrm{KD})$, indicators, material, methods, assessment and resources.

In terms of learning material, all the respondents stated the same thing. They usually prepare the learning material that they will teach to students by reading book or searching the material from the internet. This activity is in accordance with Ali Bin-Hady and Abdulsafi (2018) and Wardani in Zendrato (2016) who said that reading relevant material or considering the learning material is an activity that teachers should do in preparing a lesson plan.

R1: "I always prepare the materials before I teach. I usally read the textbook or any related book. Sometimes, I search the internet to find a new sources."

R2: "Since there is a coursebook, I do not have to search the materials anymore. I only read the material from the coursebook and figure out how to teach it with suitable method. But, sometimes I use the internet to find any related materials."

$R 3$ "Before I teach the materials to the students, I read it first, find some references, make some tasks and activities."

While in terms of learning methods, medias, and time allocation, all the respondents stated that they adjusted the methods, media and time allocation with the learning objective and materials. Besides that, students' difficulties and abilities is another factor that all the respondents considered as Ali Bin-Hady and Abdulsafi (2018) and Wardani in Zendrato (2016) said that teachers should consider students' interest and difficulties.

R1: 'Students' interest, need and difficulties become one of my concern in choosing material, method and activities."

R2: "When students have difficulties in one material, I adjust the method and the evaluation for them."

R3: "I help my students when they have problem in learning. I also guide my student to develop their interest."

Based on the results of interview and document analysis of lesson plan,it can be concluded that the lesson plan has met the minimum element and the teachers has been able to make the lesson plan in accordance with Minister of National Education and Culture Regulation Number 22 Year 2016. 


\section{Lesson Plan Implementation in Teaching and Learning Process}

The RPP that has been prepared will be applied in the learning process. Based on the interview, it was found that not all learning activities compiled in the Lesson Plan were implemented. The implementation of the Lesson Planitself based on conditions when the learning process took place. R1 mentioned that students' difficulties in understanding the material becomes one of the factors that some activities planned in the lesson plan was not implemented.

R1: "Not all the activities planned in the lesson plan can be implemented in the real process. It is because sometimes the conditions in teaching and learning process, especially when it deals with students' capacities in accepting the material. Some students are good achiever, but some of them are low achiever. This situation make the teaching and learning process becomes slower."

R3 added that time is the most problematic factor for English language learning. He said that:

R3: "The available time is not enough to teach all the materials. There are so many materials that should be taught, but the time passes by."

R2 said that some activities in the lesson plan could not be implemented because there were several disorders that often occur during the learning process, such as teachers have other needs (meeting, teachers profesionalism training, and other schools' activities).

R2: "During the semester, sometimes there are some activities that teachers should attend, such as meeting, teachers' training and other activities."

Based on the observation, some activities that was planned in the lesson plan were not implemented in the teaching and learning process.

Table. 1

Activities which were not implemented by $\mathrm{R} 1$ in teaching and learning process

\begin{tabular}{|l|l|}
\hline $\begin{array}{l}\text { Informing the core competencies, } \\
\text { basic competencies, indicators, and } \\
\text { KKM of the meeting. }\end{array}$ & Not implemented \\
\hline Make students in group & Not implemented \\
\hline $\begin{array}{l}\text { Explain the mechanism of } \\
\text { implementing learning experiences } \\
\text { according to the steps of learning }\end{array}$ & Not implemented \\
\hline
\end{tabular}

From the table above, it can be described that teachers did not always inform the KI, KD, indicators and $\mathrm{KKM}$ in the beginning of the teaching process to students. In the lesson plan, it was written that the teacher would make the 
students in group, but the activity was not implemented during the process of learning. The teacher also did not explain the mechanism of learning experiences according to the steps of learning.

Table. 2

Activities which were not implemented by $\mathrm{R} 2$ in teaching and learning process

\begin{tabular}{|l|l|}
\hline Students deliver the discussion result & Not implemented \\
\hline Students present the discussion result & Not implemented \\
\hline Discussion between students & Not implemented \\
\hline
\end{tabular}

R2 planned a discussion between students in the lesson plan, but it turns out that the discussion did not go according to the plan. So, some activities could not be implemented as the table shown.

Table. 3

Activities which were not implemented by R3 in teaching and learning process

\begin{tabular}{|l|l|}
\hline $\begin{array}{l}\text { Scheduling projects that must be } \\
\text { studied at the next meeting outside } \\
\text { school hours or at home }\end{array}$ & Not implemented \\
\hline $\begin{array}{l}\text { give rewards to groups that have } \\
\text { good performance and cooperation }\end{array}$ & Not implemented \\
\hline $\begin{array}{l}\text { discuss the benefits of completed } \\
\text { learning }\end{array}$ & Not implemented \\
\hline $\begin{array}{l}\text { Discuss the students difficulties in } \\
\text { learning }\end{array}$ & Not implemented \\
\hline
\end{tabular}

From the table above, R3 did not implement almost all activities in the closing activities of the lesson plan. He did not discuss the project that students must do for the next meeting. He also did not give the reward to the groups that have good performance and cooperation during the discussion. In addition, he did not discuss the benefit of the learning and skip to discuss the stduents' difficulties in learning.

Based on the interviews, it turns out that the things teachers most often skip are exercises, perceptions, conclusions, correcting the results of student group work and remidial activities.

R3: "Because of the limited time, I often skip the closing activities"

R2: "When students have difficulty in understanding the materials, the exercises or the task will not be given because we don't have enough time to do the exrcise activity."

R1: "In the beginning of the lesson, I rarely explain the learning objective that students mus achieve."

When some activities were not implemented during the learning process, the teachers get some solutions so the activities continue to be carried out. From the interviews, it was stated that teachers would reschedule the teaching process. The 
statement isappropriate with the results of the observation that showed when several activities were not implemented, the teachers made transactional decision.

R3: "Some activities did not implemented in the teaching process. When this is happen, I adjust the situation by other activities in another schedule."

Teacher can made a transactional desicion to modify the situation in the classroom with the planning as mentioned by Gunawan (n.d) the teachers can made transactional desicions, it means the teachers will try to adjust the situation that occurs in the classroom with the planning that has been prepared by the teachers without forgetting the objective to be achieved.

\section{CONCLUSION}

Preparation before teaching is something that teachers need to do. Without preparation, teaching will lost its direction. Teachers' preparation before teaching is usually written down in a lesson plan. An ideal lesson plan should meet minimum elements of lesson plan in order to achieve an effective teaching and learning process. Some difficulties might arise in preparing lesson plan, but teachers can discuss of how to design an ideal lesson plan with their colleagues. In this study, teachers basically have prepared a lesson plan in accordance with the standard of process. Evaluation and assessment of attitude became one of the problems in preparing a lesson plan. But, the implementation of the lesson plan in teaching and learning process showed unsatisfied results since there were some activities that teachers did not applied. This can be a consideration for teachers and schools in order to be able to carry out the learning process in a more organized manner

\section{REFERENCES}

Ali Bin-Hady, W.R., Abdulsafi, A.S.T. (2018). How Can I Prepare an Ideal Lesson-Plan?. International of English and Education. Volume:7, Issue: 4.

Copy of Attachment of the Minister of National Education Regulation Number 81a Year 2013. Implementasi Kurikulum. Jakarta.

Farid, M. (2014). Teachers Difficulties in Lesson Planning. Bandung: repository.upi.edu.

Gunawan. (n.d). Pengambilan Keputusan Transaksional dalam Pembelajaran. Malang.

Jasmi. (2014). English Teachers' Difficulties in Designing Lesson Plan Based on 2013 Curriculum. The $61^{\text {st }}$ TEFLINInternational Conference. Solo: Universitas Negeri Solo. 
Karlsson, M. (2016). What Is a Case Study?. Cited from: http://pdfs.semanticscholar.org

Marliani, B. (2017). The Problem Faced by the English Teacher in Designing Lesson Plan at SMA Muhammadiyah 3 Batu. Malang: Universitas Muhammadiyah Malang.

Minister of National Education and Culture Regulation Number 22 Year 2016. Standar Proses Pendidikan Dasar dan Menengah. Jakarta.

Neisari, A. J., \& Heidari, M. (2014). The Important Role of Lesson Plan on Educational Achievement of Iranian EFL Teachers' Attitudes. Islamic Azad University.

Permana, M. A. (2010). Analysis on the Problems Faced by Teachers in Designing Lesson Plan Based on School-based Curriculum (SBC) at SMAN 1 Sumenep. Unpublished Undergraduate Final Project.Malang: Universitas Muhammadiyah Malang.

Saputri, M. (2017). English Teachers' Difficulties in Designing Lesson Plan Based on 2013 Curriculum. A Thesis. Surakarta: IAIN Surakarta.

Zendrato, Juniriang. 2016. Tingkat Penerapan Rencana Pelaksanaan Pembelajaran Dalam Pelaksaan Pembelajaran Di Kelas. Scholaria, Vol. 6, No. 2. 